\title{
Blood lactate in a cohort of patients with severe penetrating trauma at the intensive care unit in a university hospital
}

\author{
M Gonzalez ${ }^{1}$, J Ruiz ${ }^{1}$, F Jaimes ${ }^{2 *}$ \\ From ESICM LIVES 2015 \\ Berlin, Germany. 3-7 October 2015
}

\begin{abstract}
Introduction
The usefulness of the initial serum lactate as a prognostic marker in different critical conditions has been controversial. While some consider that an initial high lactate is enough to indicate higher mortality, others consider that the really important issue is lactate clearance. Specifically in penetrating trauma, there are no studies on this matter.
\end{abstract}

\section{Objectives}

To estimate the effect of the initial values of lactate in hospital mortality of patients with severe penetrating trauma.

\section{Methods}

In a retrospective cohort from October 2013 to October 2014 we included patients over 14 years old, admitted by the emergency service with surgical penetrating trauma and attended in the intensive care unit. At least one measurement of lactate at recruitment was required, as well as information on the mechanism of trauma, injured body area, revised trauma score (RTS), APACHE II, length of stay and mortality. The relationship between lactate levels and mortality was established by means of a logistic regression model.

\section{Results}

Ninety five patients entered the institution with penetrating trauma and were subjected to surgery. However, 17 were not included in the study since they were not taken to the ICU or did not have a lactate test within the first 24 hours. Among 78 patients studied ninety six percent $(n=75)$ were men and the mean age was 29.5 years

${ }^{2}$ Universidad de Antioquia, Internal Medicine, Medellin, Colombia Full list of author information is available at the end of the article
$(\mathrm{SD}=11.4)$. The most common mechanism of trauma was a bladed weapon in $77 \%$ of the cases; $51 \%$ were exclusively wound of thorax and a $20.8 \%$ had a chest wound combined with other body area. The mean lactate level was $39.5 \mathrm{mg} / \mathrm{dL}$ on those alive and $97.6 \mathrm{mg} / \mathrm{dL}$ on the dead. The mean RTS was 5.2 and $14.1 \%$ of patients had a RTS less than 3. The APACHE II mean was 15.7 with ranges between 5 and 35 . The mean hospital stay was 12.5 days and the hospital mortality rate was $10 \%(n=8)$. The logistic regression model identified a linear relationship between the values of lactate and the risk of death, which remained after adjusting for the values of APACHE II $(\mathrm{OR}=1.025$; CI 95\% = $1.001-1.05)$.

\section{Conclusions}

The initial lactic acid level is confirmed as an independent risk factor for mortality in severe penetrating trauma in patients with postoperative management at ICU. The additional role of lactate clearance in the early hours must be defined; and the applicability of these findings depends on their replication in other institutions.

\section{Grant Acknowledgment}

Universidad de Antioquia and Hospital Universitario San Vicente Fundacion

\section{Authors' details \\ ${ }^{1}$ Universidad de Antioquia, Medellin, Colombia. ${ }^{2}$ Universidad de Antioquia, Internal Medicine, Medellin, Colombia.}

\section{Published: 1 October 2015}

\section{Reference}

1. Goodwin ML, Rothberg DL: Lactate metabolism in trauma. J Trauma Acute Care Surg 2014, 77(1):182-3, Jul.

\section{SpringerOpen ${ }^{\circ}$}

( 2015 Gonzalez et al.; This is an Open Access article distributed under the terms of the Creative Commons Attribution License (http:// creativecommons.org/licenses/by/4.0), which permits unrestricted use, distribution, and reproduction in any medium, provided the original work is properly cited. 
doi:10.1186/2197-425X-3-S1-A376

Cite this article as: Gonzalez et al:: Blood lactate in a cohort of

patients with severe penetrating trauma at the intensive care unit in

a university hospital. Intensive Care Medicine Experimental 2015

3(Suppl 1):A376.

\section{Submit your manuscript to a SpringerOpen ${ }^{\mathcal{O}}$ journal and benefit from:}

- Convenient online submission

- Rigorous peer review

- Immediate publication on acceptance

- Open access: articles freely available online

- High visibility within the field

- Retaining the copyright to your article

Submit your next manuscript at $\gg$ springeropen.com 